\title{
Parametric Study of Flat Slab Structure with Soft Storey against Earthquake Forces
}

\author{
R. Balarami Reddy ${ }^{1}$, K.Dhanasri ${ }^{2}$ \\ ${ }^{1}$ P.G Scholar (Structural Engineering), Gudlavalleru Engineering College, Gudlavalleru, A.P, India \\ ${ }^{2}$ Assistant Professor (Structural Engineering), Gudlavalleru Engineering College, Gudlavalleru, A.P, India
}

\begin{abstract}
The demand of business activities in the existing and developing cities is increasing tremendously. Due to this there is a hike in the availability of land for carrying business activities. So, the scarcity of land in these cities led to the development of high rise buildings. The requirements of the commercial buildings are faster construction, flexibility in room layout, less building height. Flat slab construction places no restrictions on the positioning of horizontal services and partitions and can minimise floor-to-floor heights when there is no requirement for a deep false ceiling. Flat slabs have a lower stiffness in comparison to a beam-column floor plan which can lead to relatively large deflections during earthquakes. In the present study a parametric investigation was carried out in order to identify the seismic response of systems flat slab building subjected to earthquake forces. A 9 storied structure was taken for the analysis to identify the seismic response and therefore strengthening by providing shear wall at various locations to reduce the lateral resistance of the structure.
\end{abstract}

Keywords: Flat slab, Soft storey, Seismic force, Shear wall, E-tabs

\section{Introduction}

A flat slab is a reinforced concrete slab supported directly by concrete columns without the use of beams. Reinforced concrete flat slabs are one of the most popular floor systems used in residential buildings, car parks and many other structures. They represent elegant and easy-to-construct floor systems. Flat slabs favour both architects and clients because of their aesthetic appeal and economic advantage. Thus it is becoming imperative to provide open ground storey and open spaces in the upper floors and providing the slab as flat slab. These provisions reduce the stiffness of the lateral load resisting system. Soft storey behaviour exhibit higher stresses at the columns. A Soft storey building is a multi-story building with wide doors, large unobstructed commercial spaces, or the ground storey is left open for the purpose of parking, i.e., columns in the ground storey do not have any partition walls. The most common structural system for the lower stories of these buildings has been the moment-resisting space frame because it can usually accommodate a parking area, commercial space, gardens, or open spaces for architectural reasons. Due to these provisions, the lateral displacement of the whole structure is governed mostly by the deformation at the lower stories. Therefore, it is essential to estimate the demand and supply in the force and deformation of the members at this part of the building to achieve a reasonable design of these structure.

Slabs are designed to fail by flexural failure, the failure mode is ductile therefore giving relatively large deflections under excessive loading, and also cracks will appear on the bottom surface before failure occurs. These signs allow the problem to be addressed before failure occurs. Punching shear failure by comparison is a brittle failure mode when shear reinforcement is not added, meaning failure will occur before significant deflections take place, in addition to this any cracks that will develop before failure will propagate from the top surface. Since this surface is typically covered, it is unlikely that there will be sufficient warning available before failure occurs.

\subsection{Problem Formulation}

In our study we are focusing on the behaviour of flat slab RCC structure with drops and flat slab with shear walls provided involves its behaviour for earthquake condition. As it is clear from previous literature that flat slab structures are unstable for seismic forces, we are investigating the effect of flat slab with soft storey in earthquake zone III. The analysis is done as per IS provision by using ETABS software. In this 4 models were compared.

\section{Modelling}

Description of building:

Type of structure: Multi-storey Flat slab RCC structure

Occupancy: Office Building

Number of stories: $9(\mathrm{C}+\mathrm{G}+7)$

Model design: These days, high-rise buildings are different in shape, height and functions. This makes each building characteristics different from each other. There are some standards for each kind of high-rise buildings, such as residential, official and commercials. However, for model designing, main factors such as grid spacing, floor shape, floor height and column section were considered. A building with $9(\mathrm{C}+\mathrm{G}+7)$ storeys having identical floor plan of $27 \mathrm{~m}$ x $45 \mathrm{~m}$ dimensions were considered for this study. The floor plans were divided into seven by five bays in such a way that centre to centre distance between two grids is 9 meters and 9 meters respectively. 


\section{International Journal of Science and Research (IJSR) \\ ISSN (Online): 2319-7064}

Index Copernicus Value (2013): 6.14 | Impact Factor (2015): 6.391

Table 1: Details of the structure

\begin{tabular}{|c|c|}
\hline Type of structure & Commercial building \\
\hline Number of floors & Cellar+Ground +7 \\
\hline Locations & Zone iii \\
\hline Type of slab & Flat slab \\
\hline Typical floor height & $3.5 \mathrm{~m}$ \\
\hline Plan dimensions & $27 \mathrm{~m} \mathrm{x} \mathrm{54m}$ \\
\hline Total height of Building & $28 \mathrm{~m}$ \\
\hline Grade of concrete & M 30 \\
\hline Grade of Steel & Fe 500 \\
\hline Panel dimension & $9 \mathrm{~m} \mathrm{x} \mathrm{9m}$ \\
\hline
\end{tabular}

Model 1: flat slab structure with perimeter beam

Model 2: flat slab structure with shear wall

Model 3: flat slab structure with shear wall at corners

Model 4: conventional RC framed structure

\subsection{Materials}

Grade of Concrete: M30

Density of Concrete: $25 \mathrm{kN} / \mathrm{m}^{2}$

Modulus of Elasticity of concrete: $5000 \sqrt{\mathrm{fck}}$ (As per IS 456:2000)

\subsection{Member dimensions}

Beam Sizes: BM $500 \mathrm{~mm}$ X600 mm

Column Sizes: $300 \mathrm{~mm}$ x $500 \mathrm{~mm}$,

$800 \mathrm{~mm}$ x $800 \mathrm{~mm}, 900 \mathrm{~mm}$ X900 mm,

Slab Thickness: $350 \mathrm{~mm}$

Thickness of wall: $230 \mathrm{~mm}$

Thickness of shear wall: $150 \mathrm{~mm}$

Drop Thickness: 100mm
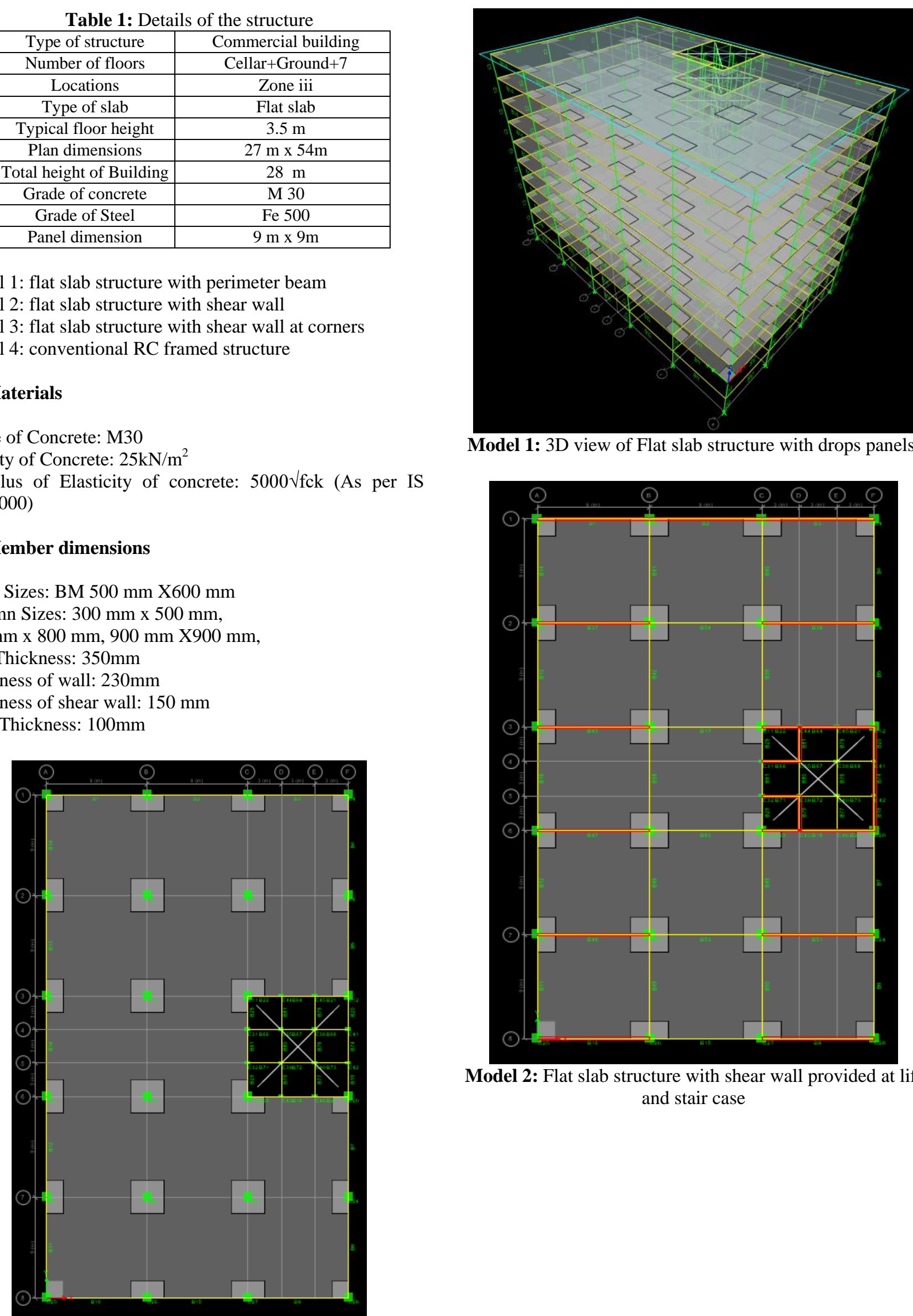

Model 1: 3D view of Flat slab structure with drops panels.

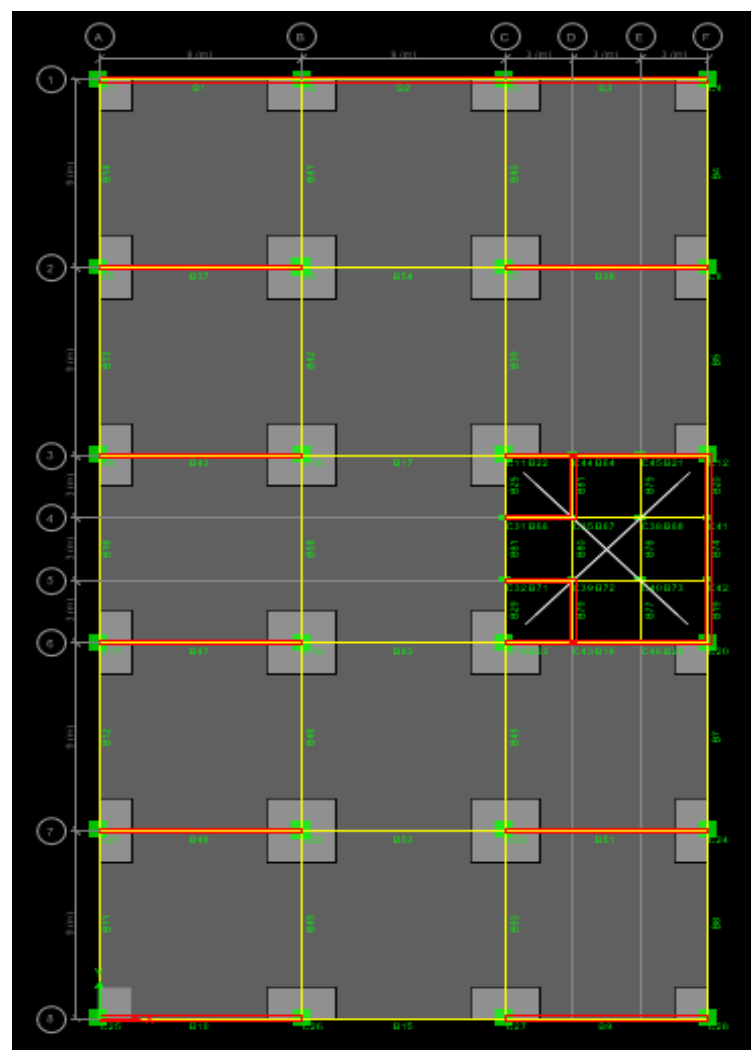

Model 2: Flat slab structure with shear wall provided at lift and stair case

Volume 5 Issue 6, June 2016 www.ijsr.net 


\section{International Journal of Science and Research (IJSR)}

ISSN (Online): 2319-7064

Index Copernicus Value (2013): 6.14 | Impact Factor (2015): 6.391

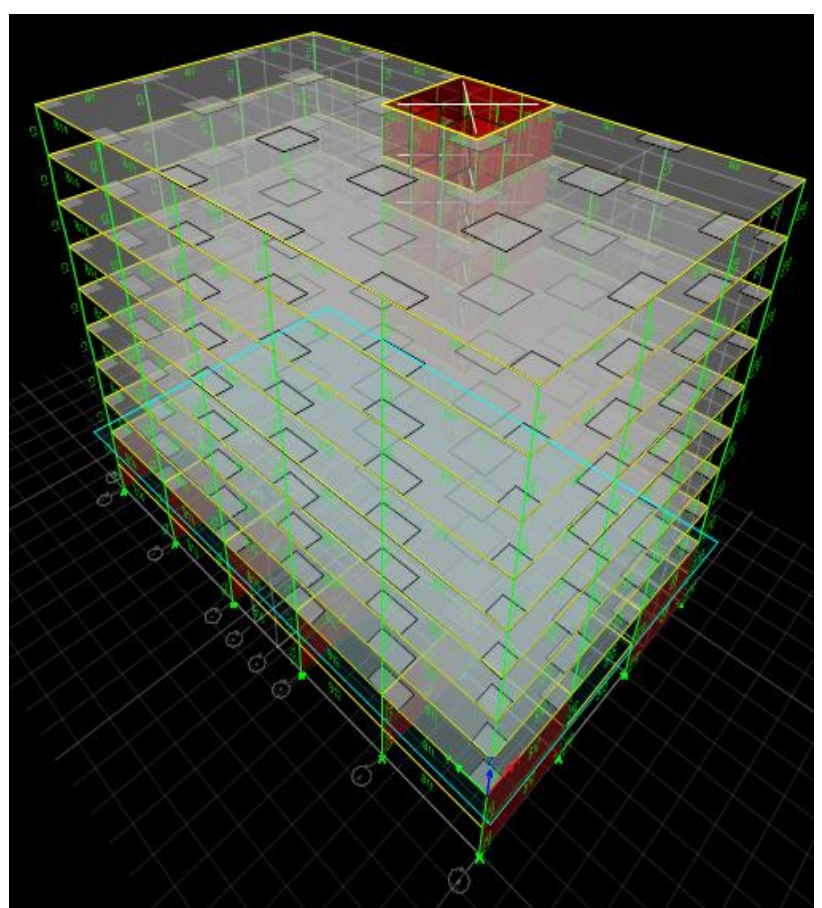

Model 2: 3D view of Flat slab structure with shear wall provided at lift and stair case

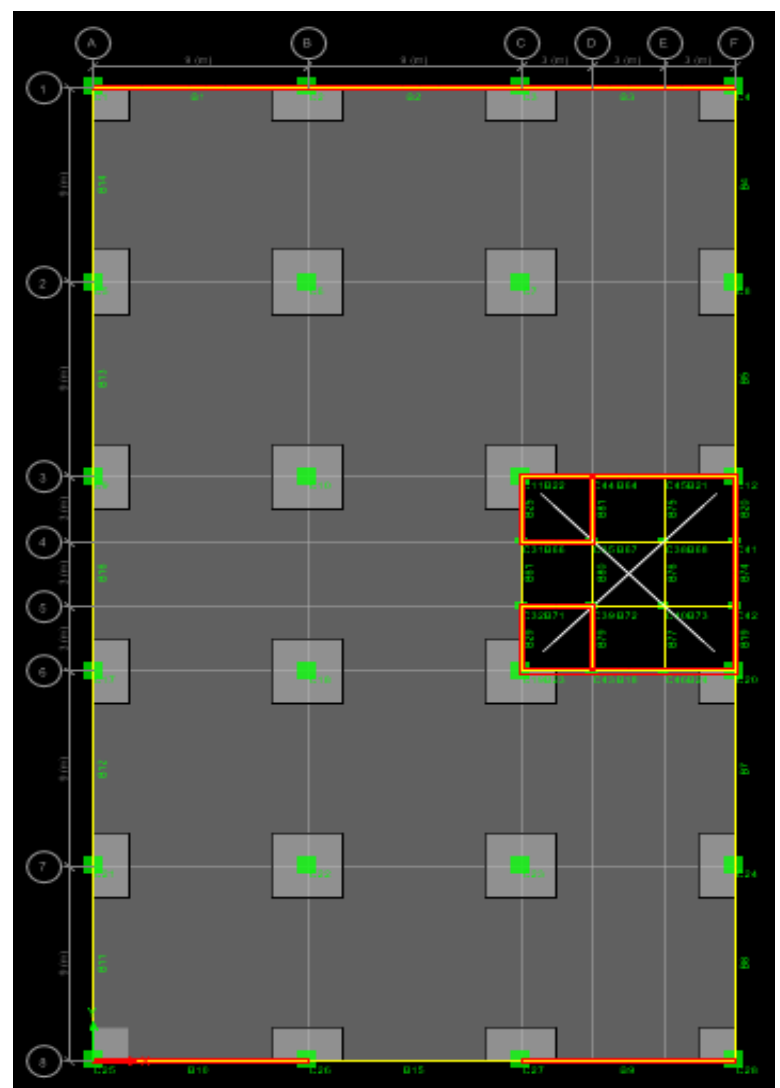

Model 3: Flat slab structure with shear wall provided at lift portion and edge portion of the structure

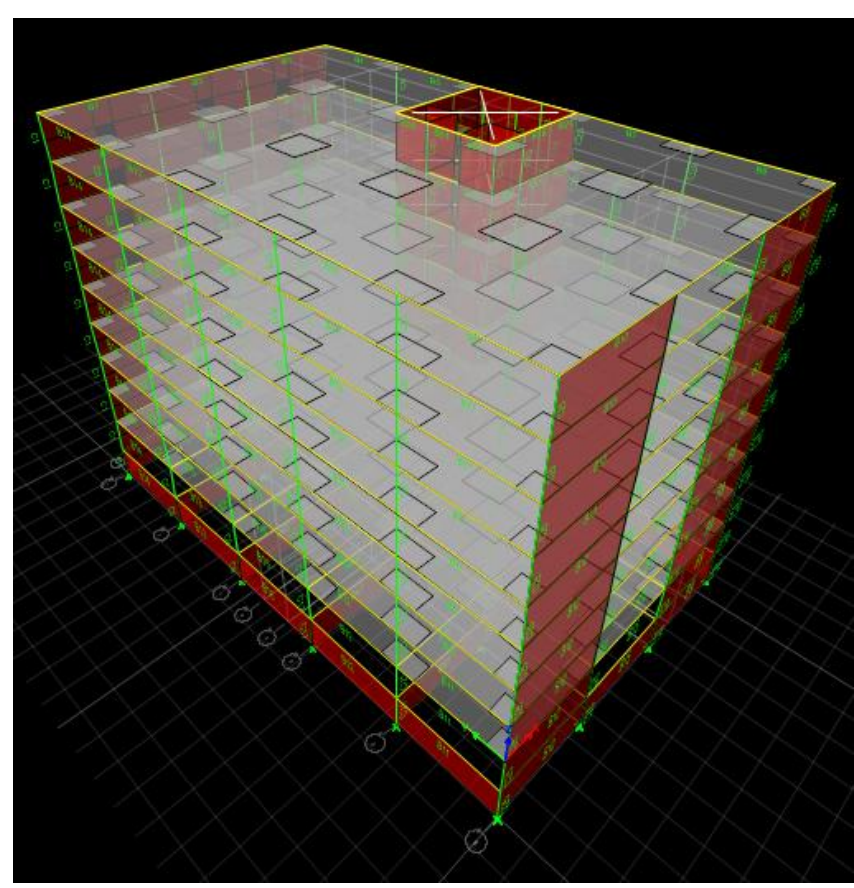

Model 3: 3D view of Flat slab structure with shear wall provided at lift portion and edge portion of the structure

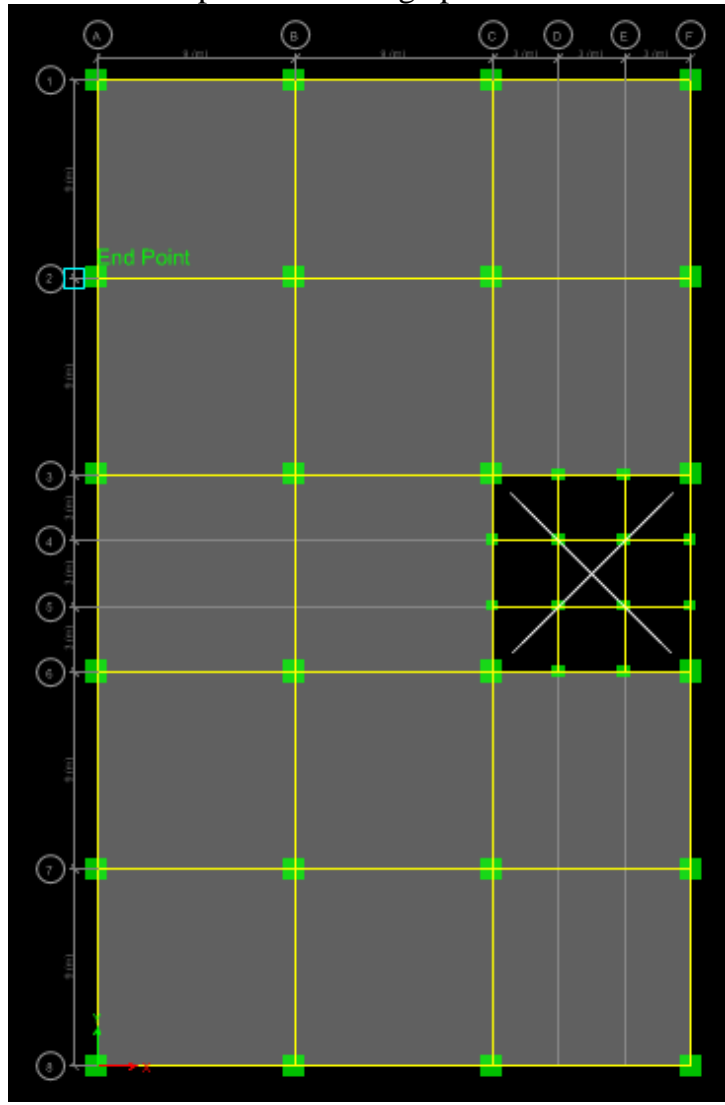

Model 4: conventional Rcc framed structure

Volume 5 Issue 6, June 2016 www.ijsr.net 


\section{International Journal of Science and Research (IJSR) \\ ISSN (Online): 2319-7064}

Index Copernicus Value (2013): 6.14 | Impact Factor (2015): 6.391

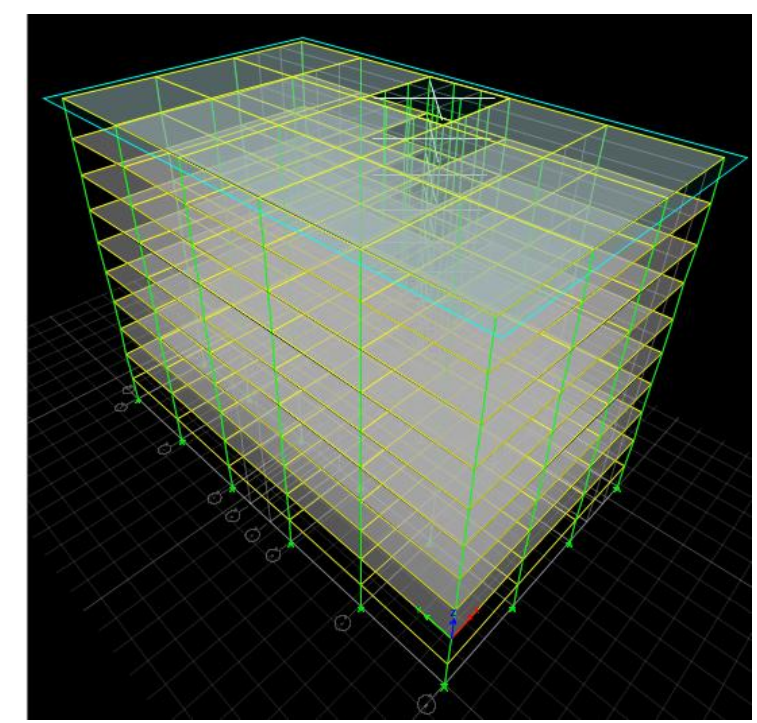

Model 4: 3D view of conventional Rcc framed structure

\section{Analysis of the Structure}

The structure is analyzed using ETABS software. All columns are having fixed supports.

\subsection{Load calculations}

\section{Dead loads}

Self-weight: $8.75 \mathrm{kN} / \mathrm{m}^{2}$

Wall load: $12 \mathrm{kN} / \mathrm{m}^{2}$

Floor finishes: $1.5 \mathrm{kN} / \mathrm{m}^{2}$

Unknown partition load: $2.5 \mathrm{kN} / \mathrm{m}^{2}$

\section{Live loads:}

Live loads on floor and roof are as given below. Reduction of live load is allowed to be considered in finding the column moments

Live load on typical floors: $5 \mathrm{kN} / \mathrm{m}^{2}$

Live load on roof: $1.5 \mathrm{kN} / \mathrm{m}^{2}$

\section{Earthquake loads:}

The seismic loads are given for following seismic parameters as per IS: 1893: 2002

a. Earthquake zone : III

b. Response reduction factor: 5

c. Importance factor : 1

d. Damping : $5 \%$

e. Soil type : Medium soil

f. Time period : $\mathrm{Ta}=0.075 \mathrm{~h}^{0.75}$

\subsection{Load combinations}

The load combinations with partial safety factor satisfying the Indian standard code provision i.e. IS: $456: 2000$, table 18, clause 18.2.3.1 and IS 1893:2002, clause 6.3.2.1 are as follows.

$1.5[\mathrm{DL}+\mathrm{LL}]$

$1.2[\mathrm{DL}+\mathrm{LL}+\mathrm{EQ}+\mathrm{X}]$

$1.2[\mathrm{DL}+\mathrm{LL}+\mathrm{EQ}+\mathrm{Y}]$

1.2[DL + LL+EQ -X]

$1.2[\mathrm{DL}+\mathrm{LL}+\mathrm{EQ}-\mathrm{Y}]$

$1.5[\mathrm{DL}+\mathrm{EQ}+\mathrm{X}]$

$1.5[\mathrm{DL}+\mathrm{EQ}+\mathrm{Y}]$
$1.5[\mathrm{DL}+\mathrm{EQ}-\mathrm{X}]$

$1.5[\mathrm{DL}+\mathrm{EQ}-\mathrm{Y}]$

$0.9[\mathrm{DL}]+1.5[\mathrm{EQ}+\mathrm{X}]$

$0.9[\mathrm{DL}]+1.5[\mathrm{EQ}+\mathrm{Y}]$

$0.9[\mathrm{DL}]+1.5[\mathrm{EQ}-\mathrm{X}]$

$0.9[\mathrm{DL}]+1.5[\mathrm{EQ}-\mathrm{Y}]$

\section{Results}

Thus from the analysis we got results shown below. Further these were used to understand the behavior of the structure (i.e. between conventional RC frame building and flat slab structure under earthquake loads).

\subsection{Displacements}

The following table shows the comparison between storey and storey displacements

Table 2: storey VS displacements

\begin{tabular}{|c|c|c|c|c|}
\hline Displacements & Model 1 & Model 2 & Model 3 & Model 4 \\
\hline 8 & 24.3 & 20.9 & 21.7 & 17.2 \\
\hline 7 & 23.8 & 20.3 & 21.1 & 16.9 \\
\hline 6 & 23 & 19.5 & 20.4 & 16.2 \\
\hline 5 & 21.8 & 18.3 & 19.2 & 15.3 \\
\hline 4 & 20.2 & 16.7 & 17.6 & 14 \\
\hline 3 & 18.1 & 14.8 & 15.7 & 12.4 \\
\hline 2 & 15.7 & 12.3 & 13.3 & 10.4 \\
\hline 1 & 12.9 & 9.5 & 10.6 & 8.1 \\
\hline ground & 8.3 & 5.8 & 6 & 5.5 \\
\hline Plinth & 3.1 & 1.7 & 1.4 & 2.6 \\
\hline base & 0 & 0 & 0 & 0 \\
\hline
\end{tabular}

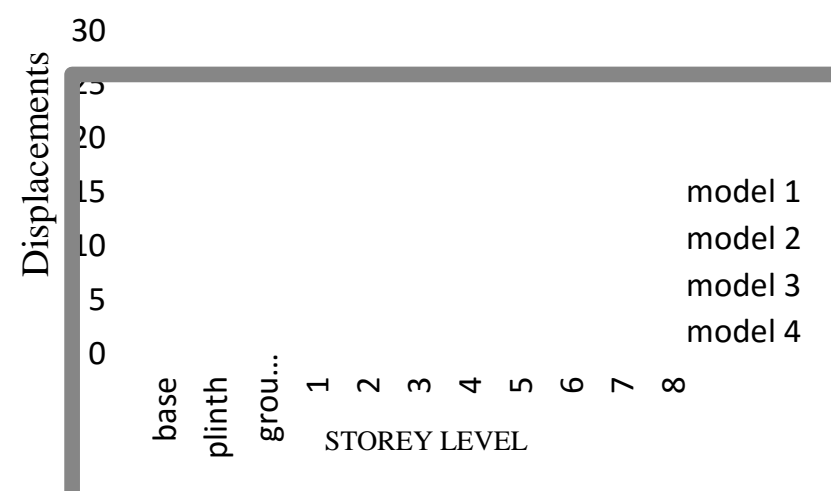

Graph 1: storey VS displacements

4.2 Axial forces

Table 3: Storey VS Axial forces

\begin{tabular}{|c|c|c|c|c|}
\hline $\begin{array}{c}\text { AXIAL } \\
\text { FORCE }\end{array}$ & MODEL 1 & MODEL 2 & MODEL 3 & MODEL 4 \\
\hline 8 & 1920 & 1947 & 1877 & 2554 \\
\hline 7 & 3886 & 3839 & 3691 & 5080 \\
\hline 6 & 5820 & 5752 & 5529 & 7616 \\
\hline 5 & 7765 & 7676 & 7381 & 10158 \\
\hline 4 & 9725 & 9618 & 9255 & 12710 \\
\hline 3 & 11704 & 11583 & 11156 & 15273 \\
\hline 2 & 13707 & 13575 & 13091 & 17851 \\
\hline 1 & 15738 & 15600 & 15064 & 20444 \\
\hline ground & 17398 & 1919 & 16681 & 23063 \\
\hline Plinth & 17654 & 9258 & 7384 & 23721 \\
\hline
\end{tabular}




\section{International Journal of Science and Research (IJSR) \\ ISSN (Online): 2319-7064}

Index Copernicus Value (2013): 6.14 | Impact Factor (2015): 6.391

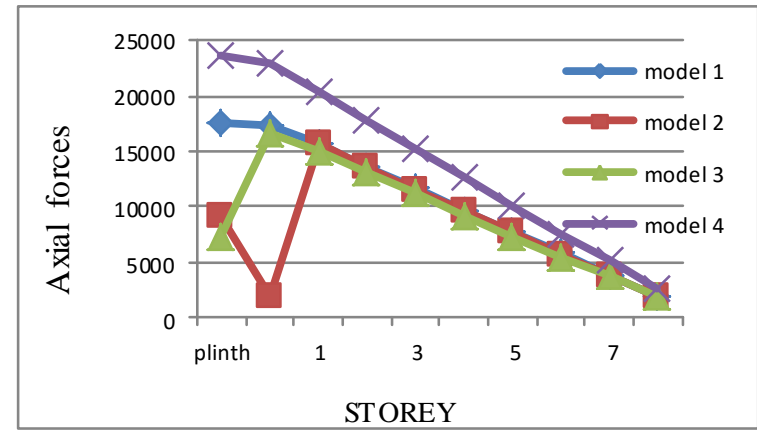

Graph 2: Storey VS axial forces

\subsection{Time periods}

Table 4: Mode VS time period

\begin{tabular}{|c|c|c|c|c|}
\hline Time periods & Model 1 & Model 2 & Model 3 & Model 4 \\
\hline 1 & 2.21 & 1.31 & 0.92 & 1.92 \\
\hline 2 & 2.11 & 0.77 & 0.52 & 1.8 \\
\hline 3 & 2.04 & 0.66 & 0.33 & 1.66 \\
\hline 4 & 0.67 & 0.39 & 0.26 & 0.58 \\
\hline 5 & 0.65 & 0.22 & 0.19 & 0.55 \\
\hline 6 & 0.62 & 0.197 & 0.18 & 0.513 \\
\hline 7 & 0.35 & 0.195 & 0.178 & 0.304 \\
\hline 8 & 0.34 & 0.19 & 0.17 & 0.289 \\
\hline 9 & 0.32 & 0.189 & 0.16 & 0.27 \\
\hline 10 & 0.227 & 0.182 & 0.15 & 0.186 \\
\hline 11 & 0.22 & 0.181 & 0.147 & 0.179 \\
\hline 12 & 0.21 & 0.172 & 0.145 & 0.178 \\
\hline \multicolumn{5}{|r}{} \\
\hline
\end{tabular}

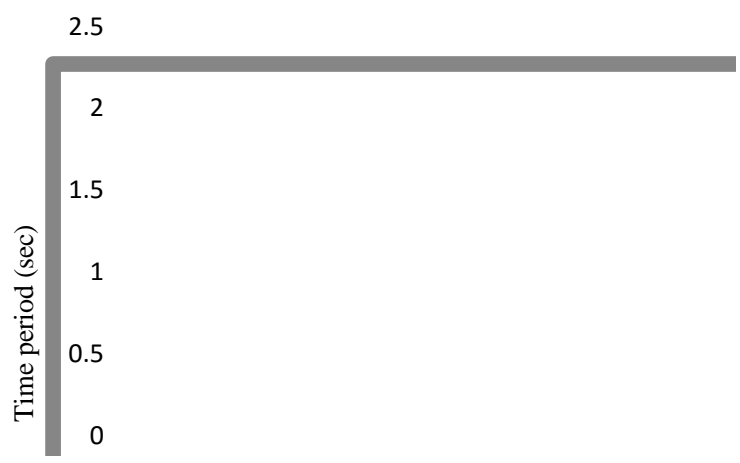

Graph 3: Mode VS Time period

\subsection{Storey Shear}

Table 5: storey VS displacements

\begin{tabular}{|c|c|c|c|c|}
\hline Story shear & Model 1 & Model 2 & Model 3 & Model 4 \\
\hline 8 & 1070 & 978 & 997 & 3203 \\
\hline 7 & 1070 & 978 & 997 & 3203 \\
\hline 6 & 1966 & 1817 & 1874 & 5918 \\
\hline 5 & 2672 & 2476 & 2555 & 8055 \\
\hline 4 & 3209 & 2979 & 3067 & 9683 \\
\hline 3 & 3601 & 3346 & 3435 & 10870 \\
\hline 2 & 3871 & 3598 & 3683 & 11687 \\
\hline 1 & 4041 & 3757 & 3837 & 12202 \\
\hline ground & 4134 & 3844 & 3918 & 12484 \\
\hline Plinth & 4167 & 3890 & 3944 & 12614 \\
\hline base & 4169 & 3893 & 3947 & 12614 \\
\hline
\end{tabular}

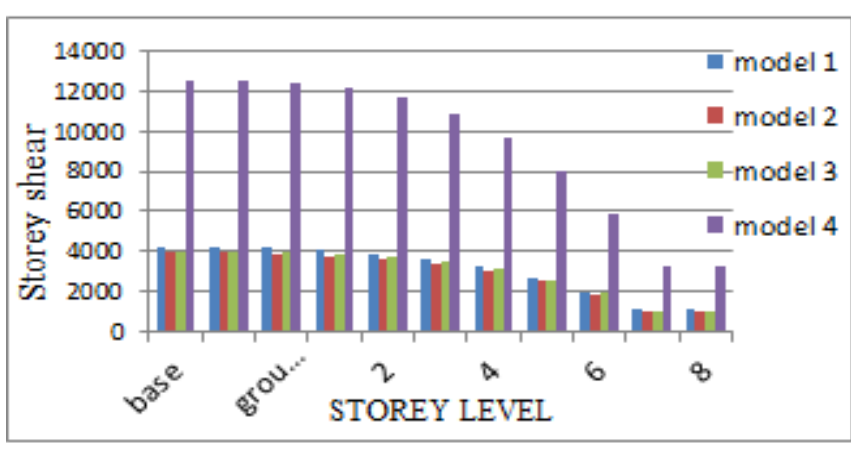

Graph 4: storey VS storey shear

\section{Conclusion}

- The Storey displacement of the flat slab structure with shear wall is $16 \%$ less compared to the other models.

- The design axial forces of conventional structure are more compared to other models the difference is nearly $47.5 \%$.The fundamental natural period value is higher in flat slab with drops compared to other models.

- The storey shear of the conventional structure is $69 \%$ more than the other models.

- Though the base shear value increases in the model 3 it gives lateral resistance much more than the normal flat slab structure.

- Thus the flat slab structure provided with shear walls at different locations is more effective structure than the remaining models.

\section{References}

[1] Gaurav joshi, K.K. Pathak and saleem akhtar "Seismic Analysis of Soft Storey Buildings Considering Structural and Geometrical Parameters" , DOI: 10.15415/jotitt.2013.12005

[2] Pradip S. Lande, Aniket B. Raut "Seismic Behaviour of Flat Slab Systems "ISSN: 2349-879X; Volume 2, Number 10; April-June, 2015 pp. 7-10

[3] Abhishek Arora "Alternative Approach to Soft Storey in Seismic Analysis of R.C.C Building Structures "ISSN: 2348 - 8352 ,SSRG International Journal of Civil Engineering (SSRG-IJCE) - EFES April 2015

[4] Bureau of Indian Standards, New Delhi, "IS 456:2000, Plain and Reinforced Concrete - Code of Practice", Fourth Revision, July (2000).

[5] IS 1893 part I-2002 criteria For Earthquake Resistant Design of Structures.

[6] Bhakti Narayan Harne, Prof. R. R. Shinde "Seismic Performance of Multi-Storied RC Building with Soft Storey" ISSN 2250-2459, Volume 5, Issue 8, August 2015

[7] Navyashree K, Sahana T.S" Use of flat slabs in multistorey commercial building situated in high seismic zone" International Journal of Research in Engineering and Technology. eISSN: 2319-1163

[8] Sanjay P N, Mahesh Prabhu K, Umesh S S, "Behaviour of Flat Slab Rcc Structure Under Earthquake Loading" IJERT- ISSN: 2278-0181.Vol. 3 Issue 5, May - 2014

[9] Alfa Rasikan, M G Rajendran" Wind Behavior of Buildings with and without Shear Wall "International Journal of Engineering Research and Applications (IJERA) ISSN: 2248-9622

\section{Volume 5 Issue 6, June 2016 www.ijsr.net}

